\title{
The therapeutic potential of a series of orally bioavailable anti- angiogenic microtubule disruptors as therapy for hormone- independent prostate and breast cancers
}

\author{
SP Newman*,', PA Foster', YT Ho', JM Day', B Raobaikady', PG Kasprzyk², MP Leese ${ }^{3}$, BVL Potter ${ }^{3}$, MJ Reed' \\ and A Purohit'
}

'Endocrinology and Metabolic Medicine and Sterix Ltd, Faculty of Medicine, Imperial College London, St Mary's Hospital, London W2 INY, UK; ${ }^{2}$ IPSENBiomeasure, 27 Maple Street, Milford, MA, USA; ${ }^{3}$ Medicinal Chemistry and Sterix Ltd, Department of Pharmacy and Pharmacology, University of Bath, Claverton Down, Bath BA2 7AY, UK

\begin{abstract}
Therapies for hormone-independent prostate and breast cancer are limited, with the effectiveness of the taxanes compromised by toxicity, lack of oral bioavailability and drug resistance. This study aims to identify and characterise new microtubule disruptors, which may have improved efficacy relative to the taxanes in hormone-independent cancer. 2-Methoxy-3-0-sulphamoyl- |7 3 -cyanomethyloestra-1,3,5( I 0)-triene (STX64I), 2-methoxy-3-hydroxy-17 $\beta$-cyanomethyl-oestra-1,3,5(I0)-triene (STX640) and 2-methoxyoestradiol-3, 17-0,0-bis-sulphamate (STX|40) were all potent inhibitors of cell proliferation in a panel of prostate and breast cancer cell lines. STX64I and STX640 significantly inhibited tumour growth in the MDA-MB-23I xenograft model. STX64I inhibited both in vitro and in vivo angiogenesis. Despite good in vivo activity, STX64I was not as potent in vivo as STXI40. Therefore, STXI 40 was evaluated in the prostate hormone-independent PC-3 xenograft model. STXI40 had superior efficacy to docetaxel, 2-MeOE2 and bevacizumab. In contrast to vinorelbine, no significant toxicity was observed. Furthermore, STXI 40 could be dosed daily over a 60 day period leading to tumour regression and complete responses, which were maintained after the cessation of dosing. This study demonstrates that STX64I and STXI40 have considerable potential for the treatment of hormone-independent breast and prostate cancer. In contrast to the taxanes, STX 40 can be dosed orally, with no toxicity being observed even after prolonged daily dosing. British Journal of Cancer (2007) 97, 1673- 1682. doi:I0.1038/sj.bjc.6604I00 www.bjcancer.com
\end{abstract}

Published online 20 November 2007

(c) 2007 Cancer Research UK

Keywords: microtubule; breast; prostate; angiogenesis

Prostate cancers initially respond to androgen ablation therapy; however, most will progress to hormone-independent disease and subsequent advanced metastatic cancer. Few efficacious treatment options are available for advanced prostate cancer, although recent studies have shown the taxanes to offer modest clinical benefit (Berry and Eisenberger, 2005). While much progress has been made in the treatment of ER-positive breast cancer, such as the recent introduction of aromatase inhibitors, fewer options are available for hormone-independent breast cancer. The taxanes, paclitaxel (taxol) and docetaxel (taxotere), are routinely used in late-stage metastatic breast cancer and have also been successfully trialled in the adjuvant and neoadjuvant setting for early breast cancer (Ring and Ellis, 2005). Although initially responsive, many tumours quickly become resistant to taxane therapy and the disease progresses. In vivo, this resistance is largely due to the expression of the P-glycoprotein pump (Fojo and Menefee, 2005) and/or the overexpression of the $\beta$ type III tubulin isoform (Burkhart et al, 2001). In addition, the toxicity of the taxanes limits

*Correspondence: Dr SP Newman;

E-mail: simon.newman@imperial.ac.uk

Revised 23 October 2007; accepted 29 October 2007; published online 20 November 2007 their use. Standard therapies with taxanes are based around a schedule of one dose every 3 weeks, and before i.v. taxane therapy can be administered the patients need to be premedicated with dexamethasone to prevent hypersensitivity reactions (Marchetti et al, 2002; Crown et al, 2004). Thus, there is an unmet need, in both hormone-independent prostate and breast cancers, to develop a new series of compounds with the antitumour properties of the taxanes but with an improved clinical profile.

Targeting tumour angiogenesis is a major focus of anti-cancer research; however, to date, few single-agent anti-angiogenic agents have entered clinical use (Eskens, 2004). There has been success in combining anti-angiogenic agents with conventional chemotherapy, such as the recent successful trial of bevacizumab with 5fluorouracil-based chemotherapy for metastatic colon cancer (Hurwitz et al, 2004). Furthermore, the potential anti-angiogenic activity of many conventional chemotherapy agents is being explored by the use of low-dose metronomic dosing, in an effort to combine their anti-tumour activity with an anti-angiogenic activity (Vacca et al, 1999; Hanahan et al, 2000; Bertolini et al, 2003). However, such dosing regimes, while likely to be anti-angiogenic, will result in the drug being used at a suboptimal dose for direct anti-tumour effects. Therefore, development of agents, which 
target the tumour cells directly, target the tumours blood supply and can be administered regularly should prove to be a productive area of research (Eskens, 2004).

One such potential agent is the natural metabolite of oestradiol, 2-methoxyoestradiol (2-MeOE2), which over the last decade has shown promise both in vitro and in vivo (Pribluda et al, 2000; Dingli et al, 2002; Lakhani et al, 2003). 2-Methoxyoestradiol is an anti-angiogenic and anti-proliferative agent in vitro ( $\mathrm{Zhu}$ and Conney, 1998; Shang et al, 2001). 2-Methoxyoestradiol inhibits the in vivo growth of xenografts derived from human MDA-MB-435 breast cancer cells, MethA sarcomas, B16 melanomas and the multiple myeloma cell line KAS-6/1 in nude mice (Fotsis et al, 1994; Klauber et al, 1997; Dingli et al, 2002). However, the in vivo efficacy of 2-MeOE2 is poor, with comparatively high oral (p.o.) or intraperitoneal (i.p.) doses of 75 and $150 \mathrm{mg} \mathrm{kg}^{-1}$ per day, respectively, being required to reduce the growth of melanoma or myeloma tumours in rodent models (Klauber et al, 1997; Dingli et al, 2002). In phase I trials, a clinical benefit was shown only in two patients who were receiving $1600-3200 \mathrm{mg} \mathrm{day}^{-1}$ 2-MeOE2 orally. The trial was stopped early due to extremely low plasma concentrations of $2-\mathrm{MeOE} 2$ even at $3000 \mathrm{mg} \mathrm{day}^{-1}$ (Dahut et al, 2006). One possible explanation is provided by the observation that 2 -MeOE2 is oxidised in vitro by tumour cell lines, which express $17 \beta$-HSD type 2 (Purohit et al, 2000; Liu et al, 2005). The gastrointestinal tract expresses $17 \beta$-HSD type 2 (Sano et al, 2001 ), and this may inactivate 2 -MeOE2 before it enters the blood stream. This is supported by data from a recent phase I trial in which a daily oral dose of $1000 \mathrm{mg} 2-\mathrm{MeOE} 2$ was given to 24 patients with advanced metastatic breast cancer. Metabolism studies showed that $80-95 \%$ of the $2-\mathrm{MeOE} 2$ was oxidised to 2-methoxyoestrone (2-MeOE1), and furthermore, $80-90 \%$ of both $2-\mathrm{MeOE} 2$ and 2-MeOE1 were present as glucuronide or sulphate conjugates. Additional evidence for the poor oral bioavailability of 2 -MeOE2 comes from the work of Ireson et al (2004), who demonstrated that 2-MeOE2 could not be detected in the plasma of rats $1 \mathrm{~h}$ after administration of a single oral dose of 2-MeOE2 $\left(10 \mathrm{mg} \mathrm{kg}^{-1}\right)$. The problems of poor bioavailability and rapid metabolism associated with this drug may be overcome by synthesising analogues resistant to conjugative and metabolic inactivation (Leese et al, 2005b). One such compound is 2-methoxyoestradiol-3,17-O,O-bis-sulphamate (STX140), whose potential anti-angiogenic and anti-tumour activities have been well documented (Day et al, 2003; Ho et al, 2003; Newman et al, 2004; Wood et al, 2004; Raobaikady et al, 2005; Utsumi et al, 2005; Leese et al, 2006).

In the present study, we characterise the recently developed (Utsumi et al, 2005) C-17-substituted compound, 2-methoxy3-O-sulphamoyl-17 $\beta$-cyanomethyl-oestra-1,3,5(10)-triene (STX641) and the corresponding nonsulphamoylated compound, 2-methoxy3 -hydroxy-17 $\beta$-cyanomethyl-oestra-1,3,5(10)-triene (STX640). Furthermore, we assess their in vivo efficacy in hormone-independent cancer and compare them with STX140.

\section{MATERIALS AND METHODS}

\section{Drug synthesis}

2-Methoxyoestrone (2-MeOE1, Figure 1, compound 1) and 2-methoxyoestradiol (2-MeOE2, Figure 1, compound 2) were synthesised by literature routes (Leese et al, 2005a). 2-Methoxyoestradiol-3,17-O,O-bis-sulphamate (STX140; Figure 1, compound 5 ) was synthesised by reaction of $2-\mathrm{MeOE} 2$ with sulphamoyl chloride in dimethylacetamide (DMA) (Leese et al, 2006). The 17cyanomethyl compounds 3 and 4 were elaborated from 2-methoxy3-O-benzyloestrone by Wadsworth-Emmons reaction followed by hydrogenolysis to afford 3. Sulphamoylation of compound 3 with sulphamoyl chloride in DMA yielded the 3-O-sulphamate derivative compound 4. Full details of these syntheses will be reported elsewhere.

\section{Cell culture}

Human umbilical vein endothelial cells (HUVECs) were obtained from TCS Cellworks (Claydon, UK) and maintained in large vessel endothelial medium supplemented with basic fibroblast growth factor / heparin, epidermal growth factor and cortisol in the presence of amphoteracin/gentomycin (TCS Cellworks). Human adult dermal fibroblasts were obtained from TCS Cellworks and maintained in fibroblast growth medium (TCS Cellworks) with the same supplements as used in the HUVEC media. MDA-MB-231 (breast ER-ve), PC-3 (prostate AR-ve), MCF-7 (breast ER + ve), A2780 (ovarian ER-ve) and LNCaP (prostate AR + ve) cancer cells were obtained from the American Type Culture Collection (LGC Promochem, Teddington, UK) and maintained in Dulbecco's minimal essential medium containing phenol red, supplemented with $10 \%$ fetal calf serum and antibiotics (Sigma, Poole, UK). All cells were cultured at $37^{\circ} \mathrm{C}$ under $5 \% \mathrm{CO}_{2}$ in a humidified incubator. HUVECs and dermal fibroblasts were used up to passage 10 .

To ascertain the $\mathrm{IC}_{50}$ values $5000-10000$ cells, in their appropriate growth medium, were added to each well of a 96well microtitre plate (Falcon; BD Biosciences, Cowley, UK). Plates were incubated for $4-5 \mathrm{~h}$ at $37^{\circ} \mathrm{C}$ in a $5 \% \mathrm{CO}_{2}$ humidified atmosphere before addition of compounds at a final concentration of $0.1 \mathrm{~nm}$ to $10 \mu \mathrm{M}$. All compounds were dissolved at $10^{-2} \mathrm{M}$ in tetrahydrofuran (THF) with a final concentration of THF of $0.1 \%$ or less. Cells were grown in the absence or presence of the compounds for 5 days. At the end of this period, MTS $(20 \mu \mathrm{l}$ per well; Promega, Southampton, UK) was added and incubated for a further $2 \mathrm{~h}$. Absorbance was recorded at $490 \mathrm{~nm}$ with a 96 -well plate reader (FLUOSTAR; BMG, Aylesbury, UK).

\section{Reversibility studies}

Cells were plated at $60-70 \%$ confluency in T-25 flasks (Triple Red, Thame, UK), and after $24 \mathrm{~h}$, they were treated with $0.5 \mu \mathrm{M}$ of the<smiles>[R]c1cc2c(cc1[2H])[C@H]1CC[C@H]2[C@@H]2CC[C@H]([R7])[C@]2(C)CC1</smiles>

$\begin{array}{llll}\mathrm{R} & \mathrm{R}_{1} & \mathrm{R}_{2} & \\ \mathrm{OH} & \mathrm{OCH}_{3} & =\mathrm{O} & (1) \\ \mathrm{OH} & \mathrm{OCH}_{3} & \mathrm{OH} & (2) \\ \mathrm{OH} & \mathrm{OCH}_{3} & \mathrm{CH}_{2} \mathrm{CN} & (3) \\ \mathrm{OSO}_{2} \mathrm{NH}_{2} & \mathrm{OCH}_{3} & \mathrm{CH}_{2} \mathrm{CN} & (4) \\ \mathrm{OSO}_{2} \mathrm{NH}_{2} & \mathrm{OCH}_{3} & \mathrm{OSO}_{2} \mathrm{NH}_{2} & (5)\end{array}$

Figure I Structures: compound I, 2-methoxyoestrone (2-MeOEI); compound 2, 2-methoxyoestradiol (2-MeOE2); compound 3, 2-methoxy-3-hydroxyI7 $\beta$-cyanomethyl-oestra-I,3,5(I0)-triene (STX640); compound 4, 2-methoxy-3-O-sulphamoyl-17 $\beta$-cyanomethyl-oestra-I,3,5(I0)-triene (STX64I); and compound 5, 2-methoxyoestradiol-3, 17-0,0-bis-sulphamate (STX|40). 
relevant compound. Control cells were treated with THF vehicle only. After 3 days, the medium was aspirated and the cell monolayers washed thoroughly. The number of cells in three flasks for each treatment was determined by Coulter counting. Of the remaining six flasks for each initial treatment, three were treated with $0.5 \mu \mathrm{M}$ of the appropriate compound, and three with vehicle alone. After a further 3 days, the remaining cells were counted using a Coulter Counter.

\section{Cell cycle analysis}

Cells were plated at $60-70 \%$ confluency in T-25 flasks. After $24 \mathrm{~h}$, they were treated with $0.5 \mu \mathrm{M}$ of compound for a further $24 \mathrm{~h}$. Control cells were untreated or treated with THF vehicle only. To harvest cells for flow cytometric DNA analysis, cells were washed with PBS before being trypsinised (0.25\% trypsin, $0.05 \%$ EDTA). Media containing nonadherent cells were also collected and pooled with the trypsinised cells. The cells and PBS washings were pelleted by centrifugation at 1500 r.p.m., washed twice with PBS, fixed in cold $70 \%$ ethanol, treated with $100 \mu \mathrm{g} \mathrm{ml}^{-1}$ RNase for $5 \mathrm{~min}$, stained with $50 \mu \mathrm{g} \mathrm{ml}^{-1}$ propidium iodide and analysed using a flow cytometer (FACScan; Becton Dickinson, Cowley, UK).

\section{Apoptosis analysis}

Cells were plated at $60-70 \%$ confluency in T-25 flasks. After $24 \mathrm{~h}$, they were treated with $0.5 \mu \mathrm{m}$ of compound. Control cells were untreated or treated with THF vehicle only. To harvest cells for flow cytometric analysis, cells were washed with PBS before being trypsinised ( $0.25 \%$ trypsin, $0.05 \%$ EDTA). Any media containing nonadherent cells were also collected and pooled with the trypsinised cells. The cells and washings were pelleted by centrifugation at 1500 r.p.m., washed twice with PBS and resuspended in binding buffer ( $10 \mathrm{~mm}$ HEPES/ $\mathrm{NaOH} \mathrm{pH} 7.4,140 \mathrm{~mm}$ $\mathrm{NaCl}, 2.5 \mathrm{mM} \mathrm{CaCl}_{2}$ ) at $1 \times 10^{6}$ cells ml$^{-1}$. Cells were then stained with fluorescein-conjugated Annexin V (BD Biosciences) antibody and propidium iodide $\left(5 \mu \mathrm{g} \mathrm{ml}^{-1}\right)$ before flow cytometric analysis. Apoptotic cells are defined as cells positive for Annexin $\mathrm{V}$ and negative for propidium iodide.

\section{Immunoblotting}

T-25 flasks seeded at approximately $2.5 \times 10^{5}$ cells per flask in $5 \mathrm{ml}$ of cell-specific media were incubated at $37^{\circ} \mathrm{C}, 5 \% \mathrm{CO}_{2}$ in a humidified incubator. After $24 \mathrm{~h}$, the compounds were added and the cells incubated for 24,48 or $72 \mathrm{~h}$. Protein was prepared from treated cells using RIPA lysis buffer (Sigma). Equal amounts of protein were loaded in all wells. Proteins were separated by electrophoresis through a $4-12 \%$ NuPAGE Bis-Tris gel (Invitrogen, Paisley, UK) and subsequently transferred to Hybond-P membrane (Amersham Biosciences, Little Chalfont, UK). Detection was carried out using an anti-human cyclin B1 (sc-752) (Santa Cruz Biotechnology Inc., Santa Cruz, CA, USA) primary antibody.

\section{Tubulin polymerisation}

The effects of test compounds (STX641, STX640 and STX140) on in vitro polymerisation of purified bovine brain tubulin (Cytoskeleton, Denver, CO, USA) were measured by turbidometry. Tubulin $\left(1 \mathrm{mg} \mathrm{ml}^{-1}\right)$ in MES buffer (0.1 M MES pH 6.5, $0.5 \mathrm{mM} \mathrm{MgCl}_{2}, 1 \mathrm{M}$ monosodium glutamate and $1 \mathrm{~mm}$ GTP) was incubated with or without test compounds $\left(10 \mu \mathrm{M}, 1 \% \mathrm{v} / \mathrm{v}\right.$ ethanol) for $5 \mathrm{~min}$ at $37^{\circ} \mathrm{C}$. Tubulin assembly was stimulated by adding paclitaxel $(10 \mu \mathrm{M})$. The change in the absorbance was continuously monitored at $350 \mathrm{~nm}$ for $15 \mathrm{~min}$ at $37^{\circ} \mathrm{C}$. Because the amount of tubulin polymerised is directly proportional to the area under the curve (AUC), it was used to determine the extent of tubulin polymerisation by different test compounds. The AUC of paclitaxel alone, with a maximal extent of polymerisation, was set to $100 \%$ polymerisation.

\section{Angiogenesis assay}

The effect of the compounds on in vitro vessel formation was assessed using an angiogenesis kit (TCS Cellworks). For this assay, endothelial cells were cultured in a 24-well plate within a matrix of human diploid fibroblasts of dermal origin in optimised medium supplied by TCS Cellworks. The co-cultured cells were incubated throughout the experiment at $37^{\circ} \mathrm{C}$ under $5 \% \mathrm{CO}_{2}$ in a humidified incubator. On day 1 , the culture medium was removed and replaced with medium containing the compounds under investigation. On days 4, 7 and 9, the medium was replaced with fresh medium containing the compounds. Each compound was tested in triplicate. On day 11, the cells were washed (in PBS) and $70 \%$ ethanol $(1 \mathrm{ml})$ was added to each well for $30 \mathrm{~min}$ to fix the cells. After fixation, the cells were washed with blocking buffer $(1 \mathrm{ml}, \mathrm{PBS}+1 \% \mathrm{BSA})$ and stained for CD31 in accordance with the manufacturer's instructions (TCS Cellworks).

The extent of vessel formation was then quantified using a variation of a previously described technique (Newman et al, 2004). Briefly, using a high-resolution transmissive scanner (ScanMaker 9800; Microtek, Willich, Germany), each well was scanned and saved as a TIF (Tagged Image Format) file in Photoshop (Adobe, San Jose, CA, USA). The image was then converted to a black and white image using the photocopy filter in Photoshop $(2 \times, 10$ Detail, 25 Darkness) and saved as an uncompressed TIF file. The files were transferred to the AngioSys software (TCS Cellworks), all background and nontubule-like structures were removed using the erode $(1 \times)$ and clean $(100$ pixels) functions, and the number of pixels representing vessels was counted. This technique was validated (data not shown) against the quantification techniques as described previously (Newman et al, 2004).

\section{Xenograft models}

Female MF-1 nu/nu mice were injected subcutaneously (s.c.) in the flank with $2 \times 10^{6}$ MDA-MB-231 cells. Twice weekly i.p. administration of STX641 $\left(40 \mathrm{mg} \mathrm{kg}^{-1}\right)$ and STX640 $\left(40 \mathrm{mg} \mathrm{kg}^{-1}\right)$ was compared with daily oral dosing of STX641 $\left(40 \mathrm{mg} \mathrm{kg}^{-1}\right)$. Dosing was performed for 28 days after which animals were euthanised and the tumours taken for histological and IHC studies.

Male MF-1 nu/nu mice were injected s.c. in the flank with $2 \times 10^{6}$ PC-3 cells. Daily oral dosing of STX140 $\left(20 \mathrm{mg} \mathrm{kg}^{-1}\right)$ was compared with $2-\mathrm{MeOE} 2100 \mathrm{mg} \mathrm{kg}^{-1}$ (daily, p.o.), bevacizumab $5 \mathrm{mg} \mathrm{kg}^{-1}(\mathrm{q} 3 \mathrm{~d} \times 4$, i.p. $)$, taxotere $30 \mathrm{mg} \mathrm{kg}^{-1}$ (qwk $\times 3$, i.v. $)$ and vinorelbine $80 \mathrm{mg} \mathrm{kg}^{-1}$ (qwk $\times 3$, p.o.). At the end of the initial 28-day study, the decision was taken to extend the dosing in STX140 arm for a further 32 days due to lack of toxicity and promising efficacy being observed.

In both studies, animal weights and tumour measurements were regularly taken using electronic callipers. Tumour volume $(\mathrm{V})$, in $\mathrm{mm}^{3}$, was determined using the following equation: length $\times$ width $^{2} / 2\left(l \times w^{2} / 2\right)$.

\section{Immunohistochemistry}

Hematoxylin-eosin (H\&E) staining and von Willebrand's factor IHC were performed on paraffin-embedded MDA-MB-231 tumour sections cut at $6 \mu \mathrm{m}$. After sectioning, rehydration and antigen retrieval steps, von Willebrand's factor antibody $(1: 800$, Abcam, Cambridge, UK) was applied to the section for $1 \mathrm{~h}$ at RT, followed by a goat polyclonal secondary antibody conjugated to FITC ( 30 min at RT). Sections were then mounted and viewed under a light or fluorescence microscope. 


\section{Statistics}

All in vitro experiments were carried out in triplicate, and data presented are representative of one of three such experiments. All errors shown are the mean \pm s.d. Student's $t$-test was used to assess the significance of the differences in cell proliferation in vitro. For xenograft data, one-way ANOVA followed by a Bonferroni's multiple comparison test was performed to determine statistical significance on most data sets. Where only two groups are compared, a Student's $t$-test was applied. All values are represented as the mean \pm standard errors of the mean (s.e.m.). Data generated in these studies were normally distributed as assessed by the method of Kolmogorov and Smirnov. Statistics were calculated using Prism 3 for Mac (GraphPad Software Inc., San Diego, CA, USA).

\section{RESULTS}

\section{Cell proliferation assays}

The ability of STX641 and the corresponding nonsulphamoylated compound STX640 to inhibit the proliferation of a panel of cell lines was examined over a 4-day period (Table 1). The replacement of the $O$-sulphamate group at the 17 position of STX140 with a cyanomethyl group, to give STX641, increased in vitro potency by two- to five-fold in the tumour cell lines tested. Removal of the 3-O-sulphamate group of STX641 to generate STX640 led to a decrease in activity. The greatest decrease in potency was seen in the PC-3 AR-ve prostate cell line, where removal of the 3-Osulphamate moiety caused over an eightfold decrease in potency ( $\mathrm{IC}_{50}$ values; 50 vs $430 \mathrm{~nm}$ ). Inhibition of HUVEC proliferation was used to assess the potential anti-angiogenic activity of these compounds. All three compounds were potent inhibitors of HUVEC proliferation with $\mathrm{IC}_{50}$ values of $<50 \mathrm{nM}$, thus indicating that these compounds may be potent inhibitors of angiogenesis.

In contrast to their effects on cancer cells and HUVECs, human adult dermal fibroblasts were relatively resistant to the antiproliferative effects of STX641, STX640 and STX140 with $\mathrm{IC}_{50}$ values in excess of $5 \mu \mathrm{m}$ (data not shown).

\section{Reversibility studies}

To assess whether the growth inhibitory effects seen were attributable to irreversible inhibition of cell proliferation or to delayed cell death, PC-3 cells were exposed to $0.5 \mu \mathrm{M}$ STX641, STX640 or STX140 for 3 days. The cells were then washed to remove the compound and cultured for a further 3 days in the absence of compound. In the prostate PC-3 cell line (Figure 2A), there was an increase in cell number following the removal of STX640 and STX140, but the rate of growth was still decreased

Table I The effect of 2-substituted, C-17-modified oestrogens on cell proliferation in a panel a cell lines $\left(\mathrm{IC}_{50}\right.$ values in $\left.\mathrm{nM}\right)$

\begin{tabular}{llccc}
\hline Cell line & Origin & STX64I & STX640 & STXI40 $^{\mathbf{a}}$ \\
\hline PC-3 & Prostate AR-ve & $50 \mathrm{a}, \mathrm{b}$ & $430 \mathrm{c}$ & 270 \\
MDA-MB-231 $\left.\right|^{b}$ & Breast ER-ve & $80 \mathrm{a}, \mathrm{b}$ & $320 \mathrm{NS}$ & 290 \\
LNCaP & Prostate AR+ve & $60 \mathrm{a}, \mathrm{b}$ & $320 \mathrm{NS}$ & 260 \\
MCF-7 & Breast ER+ve & $150 \mathrm{a}, \mathrm{b}$ & $320 \mathrm{c}$ & 250 \\
A2780 & Ovarian ER-ve & $90 \mathrm{a}, \mathrm{b}$ & $330 \mathrm{NS}$ & 280 \\
HUVEC & Endothelial & $30 \mathrm{NS}, \mathrm{b}$ & $30 \mathrm{c}$ & 44 \\
\hline
\end{tabular}

HUVEC = human umbilical vein endothelial cell. Statistics: a, STX64I vs STX640 $P<0.01$; b, STX64I vs STX|40 P<0.0I; c, STX640 vs STXI40 P<0.05; NS, not significant. a Data presented for comparative purposes previously published by Newman et al (2004) and Day et al (2003). 'Data presented for comparative purposes previously published by Utsumi et al (2005). compared to untreated cells. However, STX641 continued to cause a decline in the cell number, indicating that the cells were irreversibly committed to cell death. Similar data have been previously shown for STX140 in the hormone-independent breast cancer cell line, MDA-MB-231 (Raobaikady et al, 2005).

\section{Tubulin polymerisation}

The inhibition of paclitaxel-stimulated tubulin polymerisation in vitro is commonly observed with many microtubule destabilising agents, such as colchicine and the vinca alkaloids. Previously, it has been shown that the sulphamoylated oestrone derivative, 2-methoxyoestrone-3-O-sulphamate, inhibited the paclitaxelstimulated tubulin polymerisation, as measured by changes in turbidity (MacCarthy-Morrogh et al, 2000). In this study, both STX641 and STX140 significantly inhibited paclitaxel-stimulated tubulin polymerisation, with STX641 being the most potent inhibitor (96.6\% inhibition vs $87.8 \%$ inhibition, Figure 2B). The
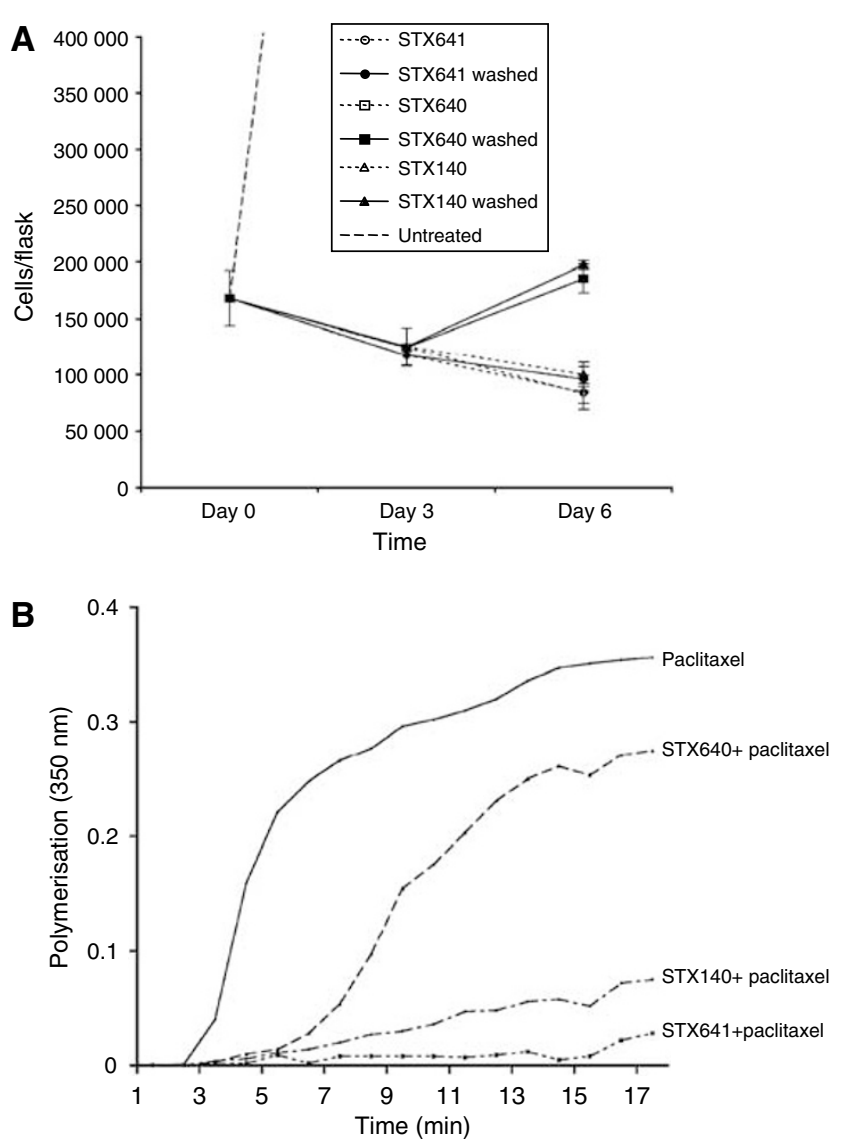

Figure 2 STX64I, STX640 and STXI40 are irreversible inhibitors of proliferation and disrupt microtubule dynamics. (A) PC-3 cells were exposed to compounds as indicated $(0.5 \mu \mathrm{M})$ for 3 days, and cell numbers were determined by Coulter counting. Cells were washed thoroughly to remove compounds, and cell numbers determined after a further 3 days: compound-free incubation (solid lines) or continued compound treatment (dashed lines). Values are means of triplicate determinations; bars, s.d. (B) In vitro tubulin assembly was measured by turbidity at $350 \mathrm{~nm}$. Tubulin was incubated with or without test compounds $(10 \mu \mathrm{M})$ for $5 \mathrm{~min}$ at $37^{\circ} \mathrm{C}$. Tubulin assembly was stimulated by adding paclitaxel (10 $\mu \mathrm{M})$. The change in the absorbance was continuously monitored at $350 \mathrm{~nm}$ for $15 \mathrm{~min}$ at $37^{\circ} \mathrm{C}$. The AUC was used to determine the extent of tubulin polymerisation by different test compounds. The AUC of paclitaxel alone, with a maximal extent of polymerisation, was set to $100 \%$ polymerisation. The AUC for the test compounds was STX640, 63\%; STX64I, 3.4\%; and STXI40, 12.2\%. 
nonsulphamoylated derivative, STX640, had some inhibitory activity (37\% inhibition), in contrast to 2 -MeOE2, which was previously shown to be inactive in this assay (MacCarthy-Morrogh et al, 2000). The vehicle alone, ethanol, had no effect on the paclitaxel-stimulated polymerisation of tubulin (data not shown).

\section{Cell cycle analysis}

It has been demonstrated that sulphamoylated derivatives of 2$\mathrm{MeOE} 1$ and 2-MeOE2 are able to induce cell cycle arrest in MCF-7, ZR-75-1, CA51 and CAMA1 cells (MacCarthy-Morrogh et al, 2000). In this study, we examined the effect of $\mathrm{C}-17$ modifications on cell cycle arrest in the hormone-independent PC-3 prostate cell line. In untreated PC-3 cells, approximately $60 \%$ of the cells are in $\mathrm{G}_{1}$ and $22 \%$ are in $\mathrm{G}_{2} / \mathrm{M}$ (Figure $3 \mathrm{~A}$ ). After treatment with $0.5 \mu \mathrm{M}$ STX641 for $24 \mathrm{~h}, 70 \%$ of PC-3 cells entered $\mathrm{G}_{2} / \mathrm{M}$ arrest, with only $6 \%$ in $\mathrm{G}_{1}$, which is almost the same distribution observed following $0.5 \mu \mathrm{M}$ STX140 treatment of PC-3 cells for $24 \mathrm{~h}$ (Figure $3 \mathrm{~A}$ ). The nonsulphamoylated compound, STX640 $(0.5 \mu \mathrm{M})$, also potently induced cell cycle arrest with $71 \%$ of PC- 3 cells being in $\mathrm{G}_{2} / \mathrm{M}$ after $24 \mathrm{~h}$ and $6 \%$ in $\mathrm{G}_{1}$.

\section{Apoptosis}

Cells exiting cell cycle arrest either continue through the cell cycle or undergo apoptosis. In this study, the capacity of STX641, STX640 and STX140 to induce apoptosis in the hormoneindependent PC-3 prostate cell line was examined by looking at Annexin $\mathrm{V}$ flip out. Apoptosing cells are detected in the $\mathrm{M}_{2}$ region of the histogram in Figure 3B. All compounds induced significant $(P<0.001)$ apoptosis after $72 \mathrm{~h}$ with respect to vehicle-treated control in PC-3 cells. Quantification of the histograms revealed no significant difference between the compounds. The data presented here compliment that of Raobaikady et al (2005), which demonstrated that STX140 induces apoptosis in the hormoneindependent breast cancer line, MDA-MB-231.

The timing of the cell cycle arrest and subsequent apoptosis was further confirmed by immunoblotting for the cell cycle protein

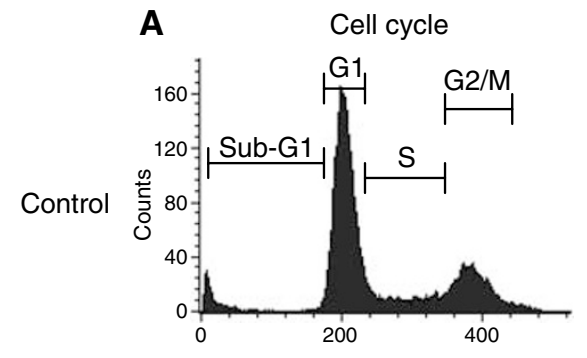

B Apoptosis
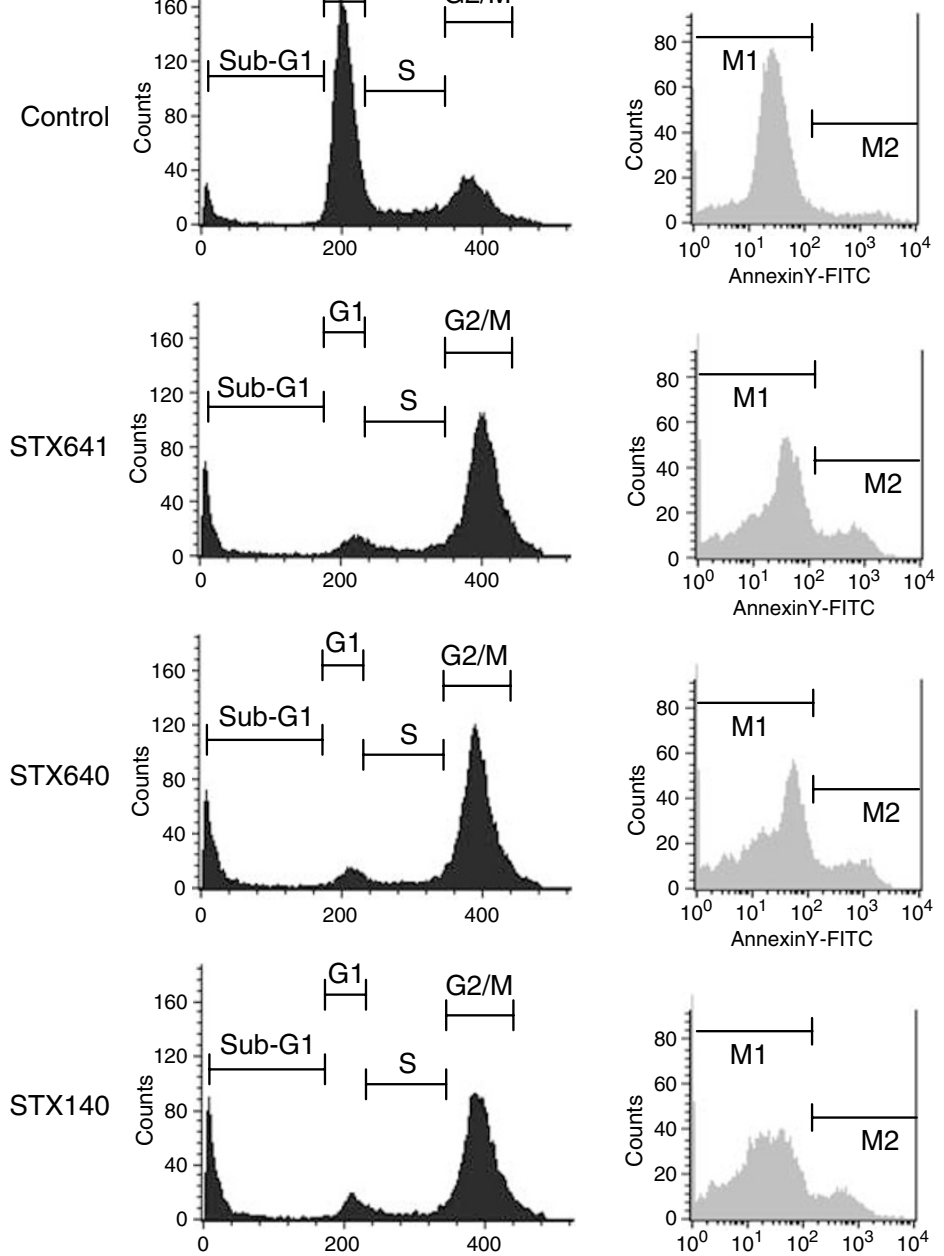
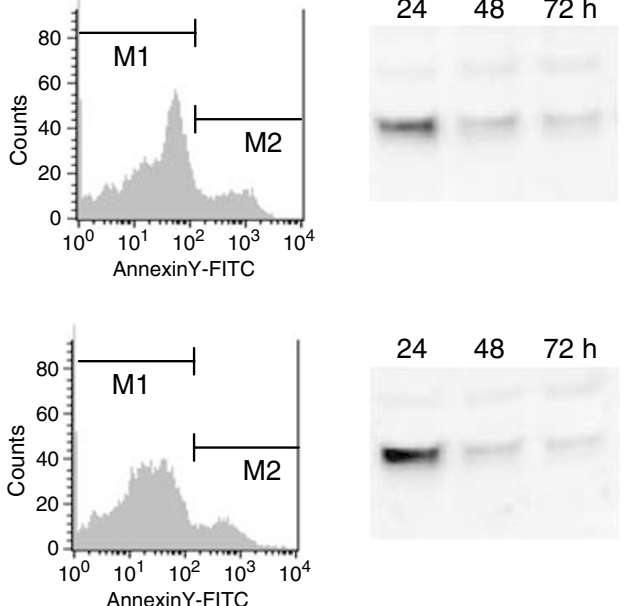

$24 \quad 48 \quad 72 \mathrm{~h}$

$24 \quad 48 \quad 72 \mathrm{~h}$

C Cyclin B1

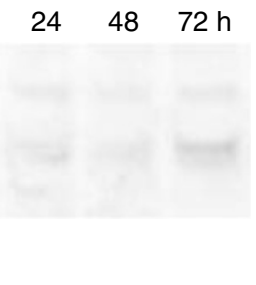

$24 \quad 48 \quad 72 \mathrm{~h}$
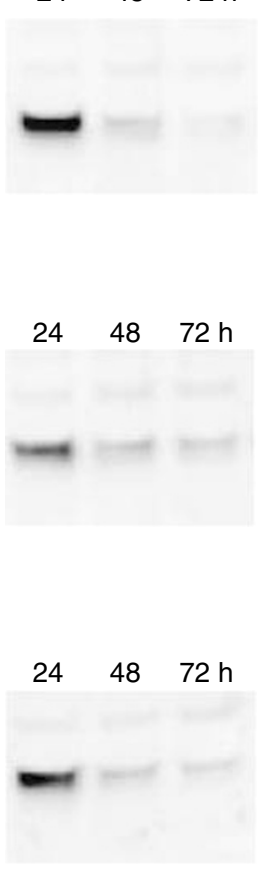

Figure 3 STX64I, STX640 and STXI 40 cause cell cycle and subsequent apoptosis in PC-3 cells. (A) PC-3 cells were treated with $0.5 \mu$ M compound for $24 \mathrm{~h}$, before being fixed and stained with propidium iodide and analysed using a flow cytometer and CellQuest Pro software. The plots represent one of at least three representative experiments. (B) To identify cells undergoing apoptosis, PC-3 cells were treated with compounds (0.5 $\mu \mathrm{M})$ as indicated for $72 \mathrm{~h}$. The cells were then harvested and stained with fluorescein-conjugated Annexin $\vee$ antibody and propidium iodide before analysis using flow cytometer and CellQuest Pro software. The cells undergoing apoptosis are in $M_{2}$ region of the histogram. The percentage of cells undergoing apoptosis is control, $4 \%$; STX640, 16\%; STX64 I, 16\%; and STX 140, I4\%. The plots represent one of at least three representative experiments. (C) Immunoblot showing induction of cyclin BI. PC-3 cells were treated with compound $(0.5 \mu \mathrm{M})$ for $24 \mathrm{~h}$, and total cell protein extracted and immunoblotted for cyclin BI. 
cyclin B1 in PC-3 cells. The induction of cyclin B1 by all three compounds coincided with the observed cell cycle arrest (Figure 3C). Once cyclin B1 levels start to decrease ( $48 \mathrm{~h}$ onwards), the cells undergo apoptosis (Figure 3B).

\section{Inhibition of in vitro angiogenesis}

As these compounds are potent inhibitors of endothelial cell proliferation (Table 1 and Newman et al, 2004), their ability to inhibit in vitro angiogenesis was assessed. In this study, a co-culture model was used in which endothelial cells are cocultured with fibroblasts in a specially formulated medium. The pro-angiogenic factor VEGF $\left(2 \mathrm{ng} \mathrm{m}^{-1}\right)$ was used to further stimulate vessel formation in this assay, and the compounds' capacity to inhibit the VEGF-stimulated angiogenesis was assessed.

The representative high-resolution scans of the wells clearly show that both $100 \mathrm{nM}$ STX641 and STX640 inhibit VEGFstimulated vessel formation (Figure 4A). Quantification of the scans, using a previously validated method (Newman et al, 2004),

A

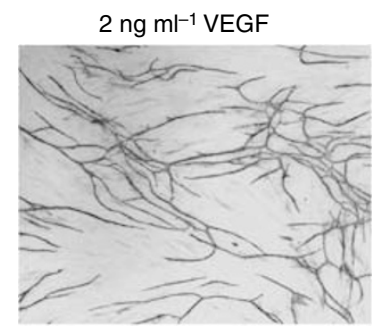

100 nм STX641+VEGF

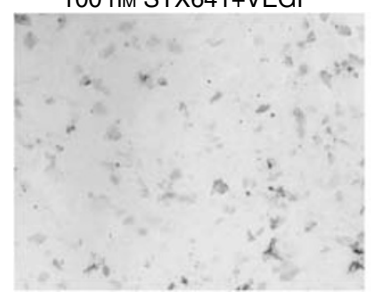

100 nм STX640+VEGF

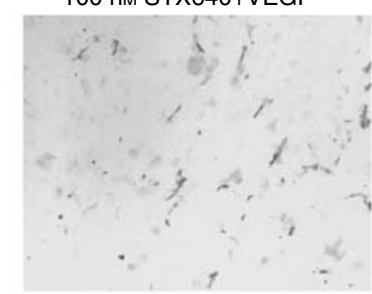

B

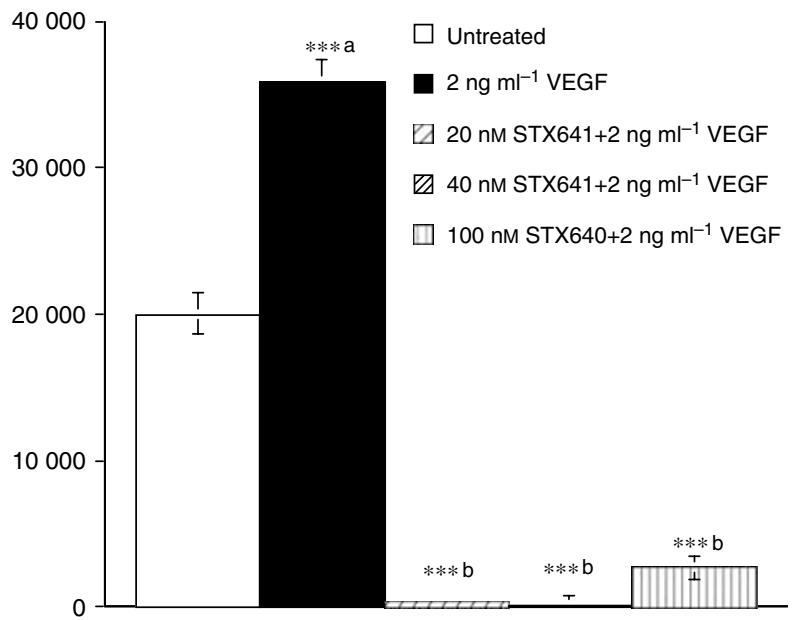

Figure 4 Vessel formation in an in vitro model of angiogenesis. (A) Representative high-resolution scans showing the effects of the indicated compounds on vessel formation by co-cultures of endothelial cells and fibroblasts. Cells were exposed to compounds for I I days, and the tubules were stained using an antibody for CD3I. (B) Co-cultures of endothelial cells and fibroblasts were exposed to compounds for II days. The tubules were stained using an antibody for CD3I and quantified by high-resolution scanning and subsequent image processing to quantify the number of pixels per well representing tubules. Values are means of triplicate determinations: bars; s.d. ${ }^{* * *}{ }^{\mathrm{a}} P<0.00$ I vs control and ${ }^{* * *}{ }^{\mathrm{b}} P<0.00$ I vs VEGF. shows that STX641 at both 20 and $40 \mathrm{~nm}$ completely blocked all tubule formation (Figure 4B). In contrast, STX140 does not completely inhibit at $20 \mathrm{~nm}$ (data not shown), although it does give complete inhibition at $100 \mathrm{~nm}$ (Newman et al, 2004). The nonsulphamoylated compound STX640 was not active at either 20 or $40 \mathrm{~nm}$ (data not shown), but did inhibit tubule formation by $92 \% \pm 2$ at $100 \mathrm{~nm}$ (Figure $4 \mathrm{~B}$ ).

\section{Xenograft studies}

The hormone-independent MDA-MB-231 breast xenograft model is a very robust and widely used model for the assessment of microtubule disruptors. Therefore, this model was initially used to assess the efficacy of STX641 and STX640 in vivo. Tumours in untreated mice increased by over $2000 \%$ in size $(2215 \% \pm 565$ s.e.m.) over the study period; in contrast, tumours in mice treated with STX640 (40 mg kg-1 i.p.; twice weekly) or STX641 (40 $\mathrm{mg} \mathrm{kg}^{-1}$ i.p.; twice weekly) were significantly smaller $(P<0.001)$ and had only increased in size by $550 \% \pm 111$ s.e. and $424 \% \pm 90$ s.e., respectively. Daily oral dosing with STX641 ( $40 \mathrm{mg} \mathrm{kg}^{-1}$ p.o.; daily) was equally as efficacious as the twice weekly i.p. dosing regime: tumours increased in size by $803 \% \pm 101$ s.e. (Figure $5 \mathrm{~A}$ ). No toxicity was associated with any regime (data not shown).

To assess the in vivo anti-angiogenic activity of these compounds $6 \mu \mathrm{m}$ sections of paraffin-embedded tumour were cut and stained for the endothelial-specific cell marker, von Willebrand's factor. STX641, both p.o. and i.p., significantly reduced the number of endothelial cells in tumour sections from treated mice relative to those in tumour sections from untreated mice (Figure 5B). H\&E staining (Figure 5C) revealed three distinct layers, a necrotic tumour centre $(\mathrm{N})$ surrounded by a healthy, viable rim (V) with a further layer of dermis (D). The tumours taken from the vehicle-treated animals generally demonstrated a larger tumour rim compared to the STX641- and STX640-treated mice.

Despite its greater efficacy in vitro (Table 1), STX641 was not as potent as STX140 in vivo. STX641 was efficacious in the MDAMB-231 xenograft model at $40 \mathrm{mg} \mathrm{kg}^{-1}$ p.o. (Figure 5A), whereas STX140 showed significantly greater efficacy at $20 \mathrm{mg} \mathrm{kg}^{-1} \mathrm{p} . \mathrm{o}$. in a hormone-independent xenograft model (Ireson et al, 2004). On the basis of these observations, STX140 was selected for evaluation in the hormone-independent prostate PC-3 cell line against a panel of preclinical and clinical comparator compounds (Figure 6A). STX140 (20 $\mathrm{mg} \mathrm{kg}^{-1}$ p.o.; daily) caused significant regression $(P<0.05)$ after 28 days relative to the starting volumes of the tumours. No other compound caused significant tumour regression at day 28 . Vinorelbine $\left(80 \mathrm{mg} \mathrm{kg}^{-1}\right.$ p.o.; qwk $\left.\times 3\right)$ prevented tumour growth, however significant weight loss was observed (Figure 6A) and two animals died during the study, indicative of significant toxicity. Docetaxel $\left(30 \mathrm{mg} \mathrm{kg}^{-1}\right.$ i.v.; qwk $\left.\times 3\right)$ significantly $(P<0.001)$ slowed tumour growth, but tumour size still increased four-fold with docetaxel dosing. Both bevacizumab $\left(5 \mathrm{mg} \mathrm{kg}^{-1}\right.$ i.p.; $\left.\mathrm{q} 3 \mathrm{~d} \times 4\right)$ and 2-MeOE2 $\left(100 \mathrm{mg} \mathrm{kg}^{-1}\right.$ p.o.; daily) had no significant effect on tumour growth relative to vehicle $(10 \%$ THF/90\% propylene glycol (PG)).

Extended ( 28 days +32 days $=60$ days $)$ daily dosing with STX140 (20 mg kg ${ }^{-1}$ p.o.) led to $5 / 8$ tumours regressing and $3 / 8$ not increasing in size. After the cessation of dosing on day 60, the growth of $5 / 8$ tumours was followed for a further 67 days (Figure 6B). Of these tumours, $2 / 5$ disappeared by day 88 and were still undetectable at the end of study $(\Delta), 1 / 5$ progressed slowly and had only increased in volume by threefold at day 127 relative to day $0(\nabla)$. The remaining two tumours grew rapidly and the animals were taken off study on day $107(\diamond)$. No significant weight loss was seen during the 60-day dosing schedule or the 67-day follow-up period (Figure 6B, inset). All the untreated tumours $(\bigcirc)$ grew rapidly, and the animals were all taken off study by day 50 as the tumours had exceeded $2000 \mathrm{~mm}^{3}$. 
A

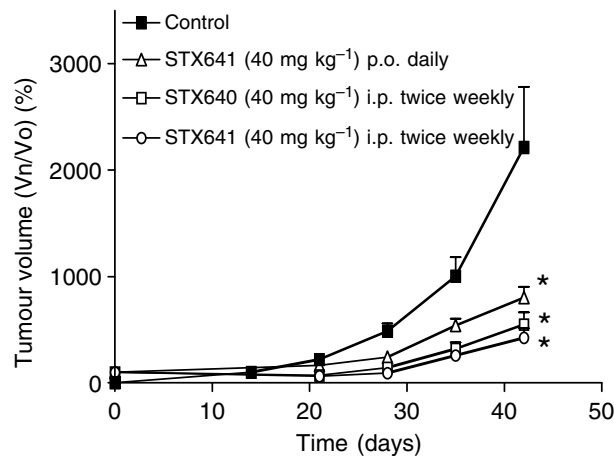

B

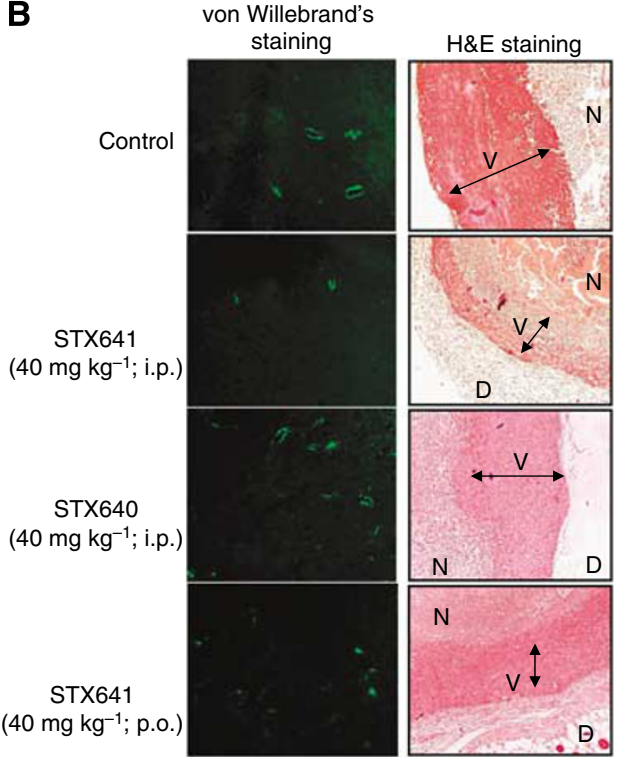

Figure 5 MDA-MB-23I xenograft studies. (A) STX64I (40 $\mathrm{mg} \mathrm{kg}^{-1}$, p.o. and i.p.) and STX640 (40 mg kg ${ }^{-1}$ i.p.) inhibited MDA-MB-23I xenograft tumour growth in vivo. Data represent mean \pm s.e.m. $(n=5)$. $* P<0.05$ when compared to vehicle control (10\% THF/90\% PG; p.o.). (B) The effect of compounds on tumour histology and vasculature. Von Willebrand's staining of blood vessels indicated that the vehicle tumours were not greatly vascularised (A). However, administration of STX64I via either p.o. or i.p. caused a decrease in blood vessels. STX640 did not affect the vasculature of the tumours. Magnification $\times 200$. In H\&E stained tumour sections $(\mathbf{B})$, three distinct areas were observed. A necrotic centre $(N)$ surrounded by a section of viable tumour rim $(V)$ with an outer dermis layer (D). The tumours of the vehicle-treated animals had a generally large tumour rim. This was smaller in the compound-treated groups, where STX64I caused a smaller rim than STX640. Magnification $\times 100$.

\section{DISCUSSION}

Recent studies by Liu et al (2005) and our group (Newman et al, 2006) have highlighted the limitations of 2-MeOE2 as a therapeutic agent due to its potential for metabolism and subsequent inactivation by $17 \beta$-HSD type 2 at the $\mathrm{C}-17$ position in the D-ring. This suggested a need for protective modification of 2-MeOE2 and other similar compounds at this position. Therefore, the effects of further $\mathrm{C}-17$ modifications to the A-ring-modified sulphamoylated compounds previously investigated by our group (MacCarthy-Morrogh et al, 2000), and, in addition, the effects of C-17 modification on the activity of a related nonsulphamoylated compound have been explored.

In vitro studies have shown STX140 to be a potent inhibitor of proliferation in a wide range of tumour cell lines, with $\mathrm{IC}_{50}$ values approximately 10-fold less than 2-MeOE2 (Day et al, 2003; Newman et al, 2004). In this study, the replacement of the 17-Osulphamate of STX140 with a cyanomethyl group significantly enhances the anti-proliferative activity. Furthermore, the nonsulphamoylated C-17 cyanomethyl compound, STX640, was approximately 10 times more potent than 2-MeOE2. These results indicate that a C-17 cyanomethyl group is able to impart antiproliferative activity on this class of compounds, even in the absence of a 3-O-sulphamate group. All three compounds caused irreversible inhibition of cell proliferation, with only minimal proliferation in STX140- and STX640-treated PC-3 cells after compound removal. Thus, further demonstrating the importance of the C-17 cyanomethyl substitution, as previous studies (MacCarthy-Morrogh et al, 2000; Day et al, 2003; Raobaikady et al, 2005) have shown the nonsulphamoylated 2-MeOE2 to be a reversible inhibitor of cell proliferation.

To further characterise the C-17 cyanomethyl derivatives, their effects on the cell cycle were assessed and compared with those of STX140 in the PC-3 cells. All compounds caused $\mathrm{G}_{2} / \mathrm{M}$ cell cycle arrest and subsequent apoptosis, there was no significant difference in efficacy between the compounds. The potency of STX640 in this assay again emphasises the value of adding a C-17 cyanomethyl group to this class of compound. The proliferation, cell cycle and apoptosis data were further supported by the improved activity of STX641 vs STX140 and STX640 vs 2-MeOE2 in the inhibition of paclitaxel-stimulated tubulin polymerisation. This highlights the potential tubulin interaction role of the C-17 cyanomethyl and possibly explains the better efficacy of C-17 cyanomethyl compounds.

2-MeOE2, STX641, STX640 and STX140 inhibit the proliferation of HUVECs, and this is an indicator of potential anti-angiogenic activity. Using a previously described (Newman et al, 2004) in vitro co-culture model of angiogenesis, the anti-angiogenic potential of STX641 and STX640 was assessed. Both compounds were potent inhibitors of VEGF-stimulated angiogenesis in this model, with STX641 being the most potent compound. In this same assay, $100 \mathrm{~nm} 2-\mathrm{MeOE} 2$ had no effect (Newman et al, 2004); in contrast, the nonsulphamoylated STX640 reduced angiogenesis by $90 \%$. The mechanisms by which 2-MeOE2 and related sulphamoylated derivatives inhibit angiogenesis have yet to be fully resolved. One likely explanation arises from the observations that both 2-MeOE2 and related sulphamoylated derivatives cause $\mathrm{G}_{2} / \mathrm{M}$ arrest in endothelial cells (Lakhani et al, 2003; Newman et al, 2004), inhibit the proliferation of endothelial cells, and the sulphamate derivatives have been shown to induce Bcl-2 phosphorylation and apoptosis in endothelial cells (Newman et al, 2004). Thus, it seems likely that in a growing tumour, the endothelial cells will be rapidly dividing to meet the tumour's demand for angiogenesis, and that this class of compound may act as a classic microtubule disruptor, inducing apoptosis in rapidly dividing cells whether they are of tumour or endothelial origin. This concept is currently being evaluated for many 'traditional' chemotherapeutic compounds, with regular, low (metronomic) dosing being used in an effort to maximise the anti-angiogenic action and maintain the anti-tumour activity (Vacca et al, 1999; Hanahan et al, 2000; Bertolini et al, 2003).

The potential anti-angiogenic activity of STX641 identified in vitro was confirmed by the reduction in staining for von Willebrand's factor, an endothelial cell-specific marker, observed 

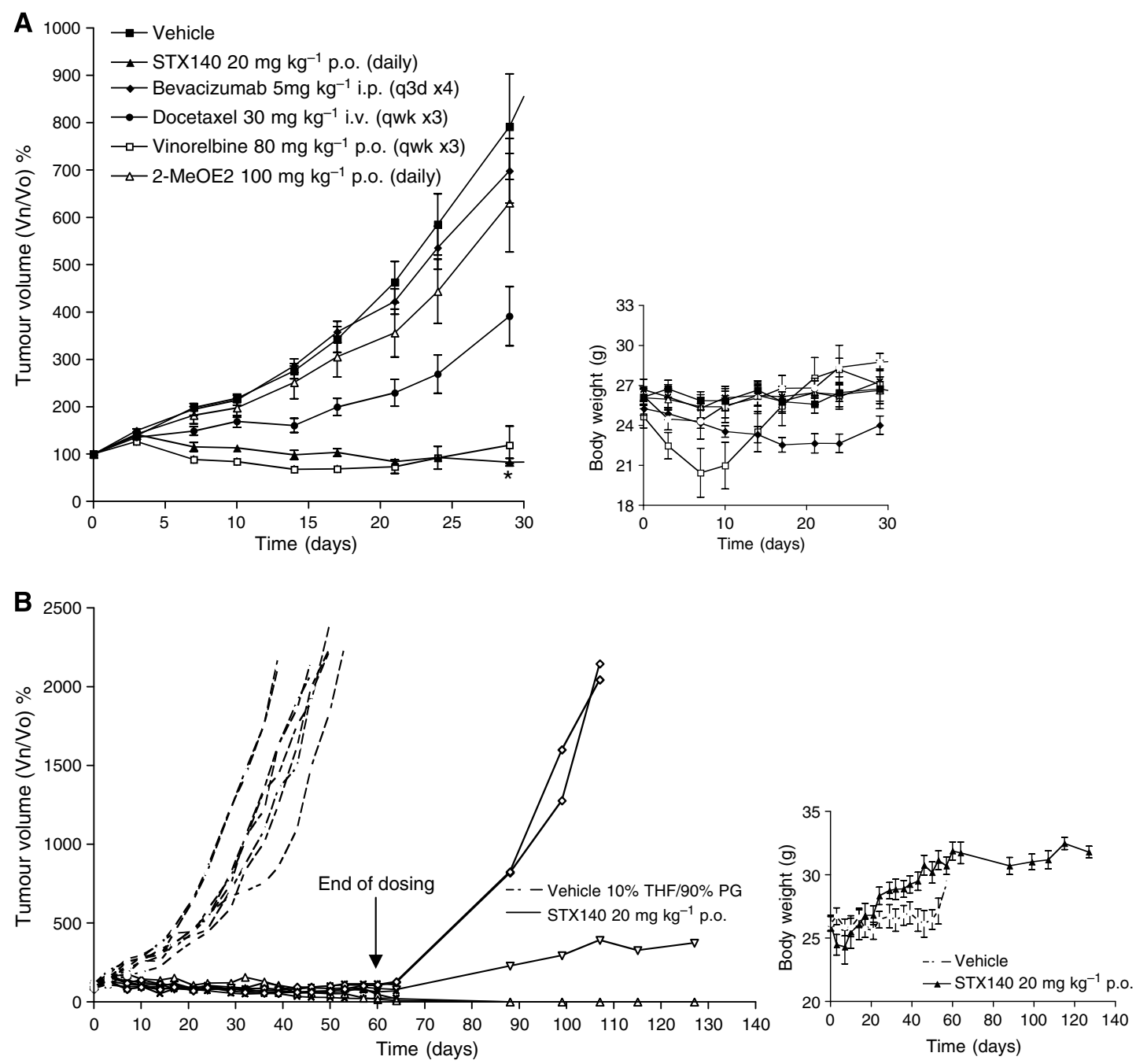

Figure 6 PC-3 xenograft studies. (A) STXI $40\left(20 \mathrm{mg} \mathrm{kg}^{-1}\right.$ p.o.; daily) was tested against a range of clinical and preclinical compounds in the hormoneindependent PC-3 xenograft model: vehicle ( $10 \%$ THF/90\% PG; p.o.), 2-MeOE2 (I $00 \mathrm{mg} \mathrm{kg}^{-1}$ p.o.; daily), bevacizumab (5 mg kg ${ }^{-1}$ i.p.; q3d $\times 3$ ), docetaxel (i.v.; qwk $\times 3)$ and vinorelbine $\left(80 \mathrm{mg} \mathrm{kg}^{-1}\right.$ p.o.; qwk $\left.\times 3\right)$. Data represent mean \pm s.e.m. $(n=8)$. *P $<0.05$ when compared to tumour starting volume. Animal weights taken over the 28-day study (inset). (B) Individual tumour data for the vehicle (I0\% THF/90\% PG) and STXI40 (20 mg kg-1 p.o.; daily) arms for the 60-day dosing schedule and the subsequent 67-day follow-up. When tumours exceeded approximately $2000 \mathrm{~mm}^{3}$, the animals were euthanised. Animal weights taken over the 127-day study (inset).

in vivo. Surprisingly, the significantly improved efficacy of STX641 in comparison to STX140 in vitro did not translate to significant improvements in vivo; in fact, comparison with STX641 shows STX140 to be more potent at inhibiting both tumour growth (Ireson et al, 2004) and in vivo angiogenesis (Chander et al, 2007). The observation that twice weekly i.p. administration of STX641 was equipotent to daily p.o. administration at the same dose $\left(40 \mathrm{mg} \mathrm{kg}^{-1}\right)$ strongly indicates that STX641 may not be as readily orally bioavailable as STX140 with the formulation used. For these reasons, STX140 was selected for further in vivo studies in the hormone-independent PC-3 prostate xenograft model. To fully assess the potential of STX641, further formulation and PK studies need to be undertaken. To evaluate STX140, it was tested against a range of clinically relevant drugs. Both STX140 $\left(20 \mathrm{mg} \mathrm{kg}^{-1}\right.$ p.o.) and vinorelbine $\left(80 \mathrm{mg} \mathrm{kg}^{-1}\right.$ p.o.) completely inhibited tumour growth over a 28 -day period. However, in contrast to vinorelbine, STX140 did not cause any significant weight loss. Docetaxel, which is commonly used to treat hormone-independent prostate cancer, only slowed the rate of tumour growth by about $50 \%$. This, taken in conjunction with its associated toxicity and lack of oral bioavailability in the clinic, indicates that there is significant room for improvement in the treatment of advanced prostate cancer.

Bevacizumab inhibits VEGF and prevents its binding to the VEGFR2 and stimulating angiogenesis. In this study, bevacizumab had no significant effect on tumour growth. The role of VEGF in sustaining the growth of PC-3 xenografts is difficult to ascertain as Takei et al (2004) showed siRNA against VEGF could reduce xenograft growth, but Dev et al (2004) showed that PC-3 cells expressed little VEGF and were not sensitive to a VEGFR2 inhibitor. The poor efficacy of 2-MeOE2 in vivo was further highlighted by its lack of activity in the PC-3 model, despite daily dosing at $100 \mathrm{mg} \mathrm{kg}^{-1}$ p.o. Data generated from this study strongly favour STX140 as a potential clinical candidate for hormoneindependent prostate cancer. Further studies could be undertaken using more sophisticated in vivo models, such as orthotopic or metastatic prostate models to expand upon these results. The use of STX140 was further supported by extended dosing studies, in which STX140 could be administered daily ( $20 \mathrm{mg} \mathrm{kg}^{-1}$ p.o.) for 60 days with no toxicity being observed. This prolonged dosing schedule produced remarkable results with complete or partial responses seen in 8/8 tumours. Furthermore, no tumours could be 
detected in the $2 / 8$ complete responses 67 days after the cessation of dosing.

This study demonstrates for the first time that addition of a C-17 cyanomethyl group significantly enhances the in vitro and in vivo efficacy of 2-MeOE2-like compounds. The cyanomethyl-substituted compounds STX640 and STX641 disrupt microtubule dynamics leading to apoptosis, and both are potent (nM range) inhibitors of in vitro angiogenesis. In vivo, in the hormoneindependent MDA-MB-231 breast xenograft model, both compounds significantly inhibit tumour growth. However, in vivo, neither compound is as potent as STX140, which was shown to be superior to a range of clinical and developmental compounds, including docetaxel and bevacizumab, in the PC-3 hormoneindependent xenograft model. Finally, data presented in this study

\section{REFERENCES}

Berry B, Eisenberger M (2005) Achieving treatment goals for hormonerefractory prostate cancer with chemotherapy. Oncologist 10(3): 30-39

Bertolini F, Paul S, Mancuso P, Monestiroli S, Gobbi A, Shaked Y, Kerbel RS (2003) Maximum tolerable dose and low-dose metronomic chemotherapy have opposite effects on the mobilization and viability of circulating endothelial progenitor cells. Cancer Res 63(15): $4342-4346$

Burkhart CA, Kavallaris M, Horwitz SB (2001) The role of $\beta$-tubulin isotypes in resistance to antimitotic drugs. Biochim Biophys Acta 1471(2): $01-09$

Chander SK, Foster PA, Leese MP, Newman SP, Potter BVL, Purohit A, Reed MJ (2007) In vivo inhibition of angiogenesis by sulphamoylated derivatives of 2-methoxyestradiol. Br J Cancer 96: 1368-1376

Crown J, O'Leary M, Ooi W-S (2004) Docetaxel and paclitaxel in the treatment of breast cancer: a review of clinical experience. Oncologist 9(Suppl 2): 24-32

Dahut WL, Lakhani NJ, Gulley JL, Arlen PM, Kohn EC, Kotz H, McNally D, Parr A, Nguyen D, Yang SX, Steinberg SM, Venitz J, Sparreboom A, Figg WD (2006) Phase I clinical trial of oral of 2-methoxyoestradiol, an antiangiogiogenic and apoptotic agent, in patients with solid tumours. Cancer Biol Ther 5(1): $22-27$

Day JM, Newman SP, Comninos A, Solomon C, Purohit A, Leese MP, Potter BVL, Reed MJ (2003) The effects of 2-substituted oestrogen sulphamates on the growth of prostate and ovarian cancer cells. J Steroid Biochem Mol Biol 84(2-3): 317-325

Dev IK, Dornsife RE, Hopper TM, Onori JA, Miller CG, Harrington LE, Dold KM, Mullin RJ, Johnson JH, Crosby RM, Truesdale AT, Epperly AH, Hinkle KW, Cheung M, Stafford JA, Luttrell DK, Kumar R (2004) Antitumour efficacy of VEGFR2 tyrosine kinase inhibitor correlates with expression of VEGF and its receptor VEGFR2 in tumour models. $\mathrm{Br} \mathrm{J}$ Cancer 91(7): $1391-1398$

Dingli D, Timm M, Russell SJ, Witzig TE, Rajkumar SV (2002) Promising preclinical activity of 2-methoxyoestradiol in multiple myeloma. Clin Cancer Res 8(12): $3948-3954$

Eskens FA (2004) Angiogenesis inhibitors in clinical development: where are we now and where are we going? Br J Cancer 90(1): 1-7

Fojo AT, Menefee M (2005) Microtubule targeting agents: basic mechanisms of multidrug resistance (MDR). Semin Oncol 32(7): S3-S8

Fotsis T, Zhang Y, Pepper MS, Adlercreutz H, Montesano R, Nawroth PP, Schweigerer L (1994) The endogenous oestrogen metabolite 2-methoxyoestradiol inhibits angiogenesis and suppresses tumour growth. Nature 368(6468): $237-239$

Hanahan D, Bergers G, Bergsland E (2000) Less is more, regularly: metronomic dosing of cytotoxic drugs can target tumour angiogenesis in mice. J Clin Invest 105(8): 1045-1047

Ho YT, Newman SP, Purohit A, Leese MP, Potter BVL, Reed MJ (2003) The effects of 2-methoxy oestrogens and their sulphamoylated derivatives in conjunction with TNF-alpha on endothelial and fibroblast cell growth, morphology and apoptosis. J Steroid Biochem Mol Biol 86(2): 189-196

Hurwitz HI, Fehrenbacher L, Hainsworth JD, Heim W, Berlin J, Holmgren E, Hambleton J, Novotny WF, Kabbinavar F (2004) Bevacizumab plus irinotecan, fluorouracil, and leucovorin for metastatic colorectal cancer. $N$ Engl J Med 350(23): 2335-2342

Ireson CR, Chander SK, Purohit A, Perera S, Newman SP, Parish D, Leese MP, Smith AC, Potter BVL, Reed MJ (2004) Pharmacokinetics and suggest that STX140 may allow for regular, oral, prolonged dosing regimes with minimal toxicity and without the need to compromise the dose used. Thus, STX140 could be regarded as a new generation of oral microtubule disruptor, which has direct antitumour activity and reduces tumour vasculature at one optimal dose. These properties suggest that this compound could be efficacious in both hormone-independent prostate and breast cancer. STX140 is envisaged to enter the clinic in 2008.

\section{ACKNOWLEDGEMENTS}

This research was supported by Sterix Ltd, a member of the Ipsen Group.

efficacy of 2-methoxyoestradiol and 2-methoxyoestradiol-bis-sulphamate in vivo in rodents. Br J Cancer 90(4): 932-937

James J, Murry DJ, Treston AM, Storniolo AM, Sledge GW, Sidor C, Miller KD (2006) Phase I safety, pharmacokinetic and pharmacodynamic studies of 2methoxyestradiol alone or in combination with docetaxel in patient with locally recurrent or metastatic breast cancer. Invest New Drugs 25: 41 - 48

Klauber N, Parangi S, Flynn E, Hamel E, D'Amato RJ (1997) Inhibition of angiogenesis and breast cancer in mice by the microtubule inhibitors 2-methoxyoestradiol and taxol. Cancer Res 57(1): $81-86$

Lakhani NJ, Sarkar MA, Venitz J, Figg WD (2003) 2-Methoxyoestradiol, a promising anticancer agent. Pharmacotherapy 23(2): 165-172

Leese MP, Hejaz HA, Mahon MF, Newman SP, Purohit A, Reed MJ, Potter BVL (2005a) A-ring-substituted estrogen-3-O-sulfamates: potent multitargeted anticancer agents. J Med Chem 48(16): 5243-5256

Leese MP, Leblond B, Newman SP, Purohit A, Reed MJ, Potter BVL (2005b) Anti-cancer activities of novel D-ring modified 2-substituted estrogen-3O-sulfamates. J Steroid Biochem Mol Biol 94(1-3): 239-251

Leese MP, Leblond B, Smith A, Newman SP, Di Fiore A, De Simone G, Supuran CT, Purohit A, Reed MJ, Potter BVL (2006) 2-Substituted oestradiol bis-sulfamates, multitargeted antitumour agents: synthesis, in vitro SAR, protein crystallography, and in vivo activity. I Med Chem 49(26): $7683-7696$

Liu ZJ, Lee WJ, Zhu BT (2005) Selective insensitivity of ZR-75-1 human breast cancer cells to 2-methoxyoestradiol: evidence for type II 17betahydroxysteroid dehydrogenase as the underlying cause. Cancer Res 65(13): $5802-5811$

MacCarthy-Morrogh L, Townsend PA, Purohit A, Hejaz HAM, Potter BVL, Reed MJ, Packham G (2000) Differential effects of estrone and estrone-3$O$-sulfamate derivatives on mitotic arrest, apoptosis, and microtubule assembly in human breast cancer cells. Cancer Res 60(19): $5441-5450$

Marchetti P, Urien S, Cappellini GA, Ronzino G, Ficorella C (2002) Weekly administration of paclitaxel: theoretical and clinical basis. Crit Rev Oncol Hematol 44: S3-S13

Newman SP, Ireson CR, Tutill HJ, Day JM, Parsons MF, Leese MP, Potter BVL, Reed MJ, Purohit A (2006) The role of $17 \beta$-hydroxysteroid dehydrogenases in modulating the activity of 2-methoxyoestradiol in breast cancer cells. Cancer Res 66(1): 324-330

Newman SP, Leese MP, Purohit A, James DR, Rennie CE, Potter BVL, Reed MJ (2004) Inhibition of in vitro angiogenesis by 2-methoxy- and 2-ethylestrogen sulfamates. Int J Cancer 109(4): 533-540

Pribluda VS, Gubish Jr ER, Lavallee TM, Treston A, Swartz GM, Green SJ (2000) 2-Methoxyoestradiol: an endogenous antiangiogenic and antiproliferative drug candidate. Cancer Metastasis Rev 19(1-2): $173-179$

Purohit A, Hejaz HA, Walden L, MacCarthy-Morrogh L, Packham G, Potter BVL, Reed MJ (2000) The effect of 2-methoxyoestrone-3-O-sulphamate on the growth of breast cancer cells and induced mammary tumours. Int J Cancer 85(4): 584-589

Raobaikady B, Reed MJ, Leese MP, Potter BVL, Purohit A (2005) Inhibition of MDA-MB-231 cell cycle progression and cell proliferation by C-2-substituted oestradiol mono- and bis-3-O-sulphamates. Int J Cancer 117(1): $150-159$

Ring ER, Ellis PA (2005) Taxanes in the treatment of early breast cancer. Cancer Treat Rev 31: 618-627

Sano T, Hirasawa G, Takeyama J, Darnel AD, Suzuki T, Moriya T, Kato K, Sekine H, Ohara S, Shimosegawa T, Nakamura J, Yoshihama M, Harada 
N, Sasano H (2001) 17 beta-Hydroxysteroid dehydrogenase type 2 expression and enzyme activity in the human gastrointestinal tract. Clin Sci (Lond) 101(5): 485-491

Shang W, Konidari I, Schomberg DW (2001) 2-Methoxyoestradiol, an endogenous oestradiol metabolite, differentially inhibits granulosa and endothelial cell mitosis: a potential follicular antiangiogenic regulator. Biol Reprod 65(2): 622-627

Takei Y, Kadomatsu K, Yuzawa Y, Matsuo S, Muramatsu T (2004) A small interfering RNA targeting vascular endothelial growth factor as cancer therapeutics. Cancer Res 64(10): 3365-3370

Utsumi T, Leese MP, Chander SK, Gaukroger K, Purohit A, Newman SP, Potter BVL, Reed MJ (2005) The effects of 2-methoxyoestrogen sulphamates on the in vitro and in vivo proliferation of breast cancer cells. J Steroid Biochem Mol Biol 94(1-3): 219-227

Vacca A, Iurlaro M, Ribatti D, Minischetti M, Nico B, Ria R, Pellegrino A, Dammacco F (1999) Antiangiogenesis is produced by nontoxic doses of vinblastine. Blood 94(12): 4143-4155

Wood L, Leese MP, Mouzakiti A, Purohit A, Potter BVL, Reed MJ, Packham G (2004) STX140 induces caspase-dependent apoptosis in CAL51 breast cancer cells and overcomes resistance to TRAIL via cooperative activation of caspases. Apoptosis 9(3): 323-332

Zhu BT, Conney AH (1998) Is 2-methoxyoestradiol an endogenous estrogen metabolite that inhibits mammary carcinogenesis? Cancer Res 58(11): $2269-2277$ 